\title{
MULTIVARIATE ANALYSIS FOR THE DETECTION OF Passiflora SPECIES RESISTANT TO COLLAR ROT
}

\author{
ANÁLISE MULTIVARIADA NA DISTINÇÃO DE ESPÉCIES DE Passiflora \\ RESISTENTES À PODRIDÃO DO COLO
}

\section{Sandra da Costa PREISIGKE ${ }^{1}$; Leonarda Grillo NEVES ${ }^{2}$; Kelly Lana ARAÚJO² Nayaro Renero BARBOSA ${ }^{3}$; Milson Evaldo SERAFIM ${ }^{4}$; Willian KRAUSE ${ }^{5}$}

1. Doutoranda em Genética e Melhoramento de Plantas, Universidade Estadual do Norte Fluminense Darcy RibeiroUENF, Campos dos Goytacazes, RJ, Brasil; 2. Professora, Doutora, Departamento de Agronomia, Universidade do Estado de Mato Grosso - UNEMAT, Cáceres, MT, Brasil; 3. Aluno, Departamento de Agronomia, Universidade do Estado de Mato Grosso - UNEMAT, Cáceres, MT, Brasil; Professor, Doutor, Departamento de Agronomia, Instituto Federal do Mato Grosso - IFMT, Cáceres, MT, Brasil; 4. Professor, Doutor, Departamento de Agronomia, Universidade do Estado de Mato Grosso - UNEMAT, Tangará da Serra, MT, Brasil.

\begin{abstract}
Collar rot is a disease difficult to control that has hindered passion fruit cultivation in many regions of Brazil. Therefore, this study aimed to find genetic resistance to the fungus Fusarium solani in Passiflora species using the multivariate analysis methodology to discriminate the most resistant species. The following fourteen Passiflora species were assessed: $P$. quadrangularis, $P$. nitida, $P$. foetida, . tenuifila, $P$. alata, . setacea, . cincinnata, $P$. mucronata, $P$. micropetala, $P$. suberosa, $P$. morifolia, $P$. eichleriana, $P$. edulis and $P$. coccinea. These plants were arranged in a casualized block design with 14 treatments (species), three replications and three plants per plot. The reactions of the inoculated species of Passiflora were evaluated with the use of 12 resistance traits. The generalized Mahalanobis distance was used to form groupings by the UPGMA method. 3D projection with the canonical variables and quantification of the relative contribution of characters were also conducted. The UPGMA method revealed the formation of three distinct groups of species, which composed the susceptible, moderately resistant and resistant groups. The groups formed by threedimensional dispersion were similar to those formed by the dendrogram. The following traits contributed most to genetic diversity: inoculation time until the lesion reached more than $50 \%$ of the circumference of the injured stem and area under the curve of the expansion of the lesion width. The use of the set of traits and their joint assessment through multivariate analysis allowed greater accuracy in the inference of the most resistant species, mainly $P$. nitida and $P$. cincinnata.
\end{abstract}

KEYWORDS: Passion fruit. Fusarium solani. Genetic resistance.

\section{INTRODUCTION}

Sour passion fruit belongs to the genus Passiflora and is the largest and most important genus of the family Passifloraceae. About 139 species of Passiflora (BERNACCI et al., 2014) are known in Brazil, of which 83 are endemic and can be used as medicine, ornaments and food. About 70 species produce edible fruits (CUNHA et al., 2002). Despite this wide variability, the species Passiflora edulis Sims (both yellow and purple fruits), particularly, has high economic value, since it accounts for approximately $95 \%$ of the Brazilian Passiflora orchards (MELETTI, 2011).

In addition to its wide variety of passion fruit species, Brazil has emerged, since the 70s, as the world's largest producer of this fruit. However, there was a slight drop in production (IBGE, 2014) in the 2012 harvest, partly due to phytosanitary problems. Diseases caused by soilborne pathogens are the main cause of economic losses (FISCHER et al., 2005; MELETTI; BRUCKNER, 2001). Among these, a major disease attacking sour passion fruit in most producing states is collar rot, which is caused by the fungus Fusarium solani. This disease significantly reduced productivity and led to constant migration of the culture for pathogen-free regions (FISCHER et al., 2005). The fungus produces abundant resistance structures, the chlamydospores, which are difficult to eradicate from infested areas and difficult to control (FISCHER and REZENDE, 2008).

The chemical control of collar rot has been tested (FISCHER et al., 2010b; SILVA et al., 2014), but its efficiency is still incipient because of the residues that remain in the soil and the increased production costs. Moreover, the characterization and exploitation of genetic variability among species of Passiflora may provide valuable sources of resistance for the control of these diseases in the field (use as rootstock) or use in breeding programs.

The development of improved cultivars requires the exploration of genetic variability among species of Passiflora, which may be used as valuable sources of resistance for breeding programs. For such, the characterization methods 
must be effective. The studies on the characterization of Passiflora resistance to $F$. solani used few traits to assess resistance, including incidence of plants that were wilted, dead or with symptoms (FISCHER et al., 2010b) and lesion length (FISCHER et al., 2005; FISCHER et al., 2010a). Moreover, each trait was analyzed individually. The use of multivariate analysis may be an alternative to this, since it allows the simultaneous analysis of many characteristics, which may increase the accuracy and precision of the evaluation and determination of the best parents. Thus, this study aimed to propose the use of multivariate analysis in the evaluation of genetic resistance to $F$. solani in Passiflora species in order to find species resistant to the fungus.

\section{MATERIAL AND METHODS}

The experiment was conducted in the city of Cáceres, in the southwestern Mato Grosso State. The following fourteen species of Passiflora from the Active Germplasm Bank of the State University of Mato Grosso (UNEMAT), in Cáceres, were sown: $P$. quadrangularis, $P$. nitida, $P$. foetida, $P$. tenuifila, $P$. alata, $P$. setacea, $P$. cincinnata, $P$. mucronata, $P$. micropetala, $P$. suberosa, $P$. morifolia, $P$. eichleriana, $P$. edulise and $P$. coccinea. After the plants developed, they were transplanted to plastic bags and kept in a greenhouse.

When the plants reached about $\pm 30 \mathrm{~cm}$ of height, inoculation was performed with the monosporic isolate FS04 from the fungus Fusarium solani from the mycology collection of the UNEMAT Plant Genetic Breeding Laboratory, Cáceres campus. To prepare the inoculum, the isolate FS04, which had been preserved on filter paper, was transferred to Petri dishes with BDA medium and incubated in a growth chamber (BOD) at the temperature of $24^{\circ} \mathrm{C}, 12 \mathrm{~h}$ photo-period, for seven days. The inoculation procedure was similar to that described by Fischer et al. (2003). After inoculation, the plants were arranged in a randomized block design with 14 treatments (Passiflora species), with three replications and three plants per plot.

The reactions of the inoculated plants were analyzed for 12 resistance traits, namely: length (CL) and width (LL) of the injury; number of plants on which the injury occupies less than $50 \%$ of the circumference (NPL-50\%P); inoculation period until the injury reaches more than $50 \%$ of the circumference of the injured plant stem (PILA + $50 \%$ ); inoculation period until the injury reaches $100 \%$ of the circumference of the injured plant stem
(PILA100\% C); number of plants whose injury reached the marrow (NPLAM); normalized area under the curve of expansion of the injured area (AACEAL); normalized area under the curve of expansion of the width of the injury (AACELL); Normalized area under the curve of the length of injury (AACECL); inoculation period until plants wither (PIPM); period of survival (PS); and the number of dead plants (NPM).

The assessments of all treatments (genotypes) started on the fifth day after inoculation (DAI), and were conducted every other day until 59 DAI or until the death of the plant. The length of the injuries and the width of the necrotic area were measured with the aid of a digital caliper. The injured area $\left(\mathrm{AL}, \mathrm{mm}^{2}\right)$ was estimated using the formula for calculating the area of an ellipse $\left(\pi^{*} C^{*} L / 4\right)$, where $C$ is the length of the injury and $L$ is the width of the injury.

Following the measurements of the length and width of injuries and the calculation of the area of the injuries throughout the assessment period, AACEAL, AACECL and AACEALL were calculated based on the equation proposed by Shaner and Finney (1977). For the purposes of comparisons between the treatments, due to the variation in the times of observation, the variables AACEALL, AACEAL and AACECL were separated according to the respective observation period (period of days between the first and the last measurement of the injury) (FRY, 1977).

Some information about resistance characteristics was submit to analysis of variance and got their significance tested by test $F$. This significance had followed the statistic model $X i j=$ $\hat{m}+t i+b j+e i j$, where $X i j$ is the founded value regarding the portion that received the ' $i$ ' treatment at ' $j$ ' repetition, $\hat{m}$ is the general average, $t i$ is treatment effect, $b j$ is the block effect and eij is the experimental error effect, being normally distributed with zero average and $\sigma^{2} e$. The characteristics so called NPLAM and NPL-50\%P was not submit to analysis of variance, because they do not follow the assumption of normality.

The multivariate analysis of the resistance traits was used by applying the clustering and canonical variate techniques. In the clustering technique, the generalized Mahalanobis distance was used as a measure of dissimilarity and for delimiting the groups, while a dendrogram was created using the Unweighted Pair Group Method with Arithmetic Mean (UPGMA). In the canonical variate analysis, genetic diversity was evidenced by 3D projection with the first three variables, in order to obtain the graphic dispersion in three-dimensional 
space of the genotypes studied, for the epidemiological variables related to stem rot in Passiflora. Additionally, the relative contribution of the traits for genetic divergence related to resistance to $F$. solani was quantified through the generalized Mahalanobis distance, using the criterion proposed by Singh (1981). All statistical analyses were performed using the Genes software system (Cruz, 2013).

\section{RESULTS AND DISCUSSION}

The analysis of variance (table 1) revealed a big difference between the average of species with probability at $1 \%$ and most of resistance characteristics, except at PIPM, AACELL and AACECL, whose were not found with significance effect - this fact showed us that, to those characteristics, there are no differences between species.

Five days after inoculation, it was observed the death of plants of the following species: $P$. alata,
P. suberosa, $P$. coccinea, $P$. micropetala and $P$. setacea. These species showed early death, and were considered very susceptible to the pathogen because they survived for a short time in the presence of the fungus. During the period of evaluation, it was observed that, in some species, the number of dead plants and the size of the injuries decreased with time.

The highest amplitude of the generalized Mahalanobis distances $\left(\mathrm{D}^{2}\right)$ was found between $P$. nitida and $P$. coccinea (152.12) and the lowest, between $P$. nitida and $P$. cincinnata (5.76). Regarding genetic resistance to $F$. solani, the species $P$. nitida and $P$. coccinea are the most dissimilar, while $P$. nitida and $P$. cincinnata are the most similar. These results also indicate that the most distant species, $P$. nitida and $P$. coccinea, showed the greatest difference with respect to resistance, and the species $P$. nitida showed the best performance against the pathogenicity of the fungus, whereas $P$. coccinea showed high susceptibility.

Table 1. Summary of the analysis of variance of genetic resistance traits of 14 species of Passiflora as the $F$. solani

\begin{tabular}{ccccccc}
\hline Source of & \multirow{2}{*}{ G.L } & \multicolumn{5}{c}{ SQM } \\
\cline { 3 - 7 } variation & & LL & CL & NPM & PS & PILA+50\% \\
\cline { 3 - 7 } blocks & 2 & 22,63 & 10,00 & 1,92 & 580,76 & 93,83 \\
Species & 13 & $12,41^{* *}$ & $28,07 * *$ & $2,77 * *$ & $681,09 * *$ & $632,57 * *$ \\
residues & 26 & 1,69 & 4,8441 & 0,56 & 137,72 & 62,56 \\
\hline C.V $(\%)$ & & 16,24 & 15,47 & 81,28 & 26,33 & 40,27 \\
\hline Source of & \multirow{2}{*}{ G.L } & \multicolumn{5}{c}{ SQM } \\
\cline { 3 - 7 } variation & 2 & PIPM & PILA100\%C & AACEAL & AACELL & AACECL \\
\cline { 3 - 7 } blocks & 2928,10 & 504,00 & 465,80 & 0,17 & 15,89 \\
Species & 13 & $722,67 *$ & $479,00 * *$ & $6466,99 * *$ & $7,52^{\text {ns }}$ & $39,12^{\text {ns }}$ \\
residues & 26 & 183,22 & 78,25 & 1817,57 & 4,18 & 22,13 \\
\hline C.V $(\%)$ & & 31,70 & 37,80 & 46,12 & 63,52 & 54,60 \\
\hline
\end{tabular}

$(* *)$ the significant $1 \%,\left(^{*}\right)$ the significant $5 \%$ e (ns) not significant, the test F; LL width of lesion; CL - lesion length; NPM- number of dead plants; PS - survival period; PILA $+50 \%$ - period from inoculation until the lesion reaches more than $50 \%$ of the circumference of the plant; PIPM- Period from inoculation until the plant withers; PILA100\%C - period from inoculation until the lesion reaches $100 \%$ of the circumference of the plant; AACEAL- normalized area under the expansion curve of the area of the lesion; AACELL- normalized area under the curve of expansion of lesion width; AACECL- normalized area under the curve of the length of the lesion; NPLAMnumber of plants whose injury reaches the marrow of the plant; NPL-50\% P- number of plants whose injury reached less than $50 \%$ of the circumference of the plant.

Based on the relative magnitude of the Mahalanobis distance values obtained through 12 resistance traits and considering $60 \%$ of the generalized Mahalanobis distance, the UPGMA grouping method can demonstrate the formation of three distinct groups (Figure 1), namely, susceptible, moderately resistant and resistant. The first group was composed of the species $P$. alata, $P$ setacea, $P$. suberosa, $P$. micropetala and $P$. coccinea. These species form the group of the most susceptible genotypes, which presented the greatest number of dead plants. Some plants died after five days of inoculation and showed the largest injured area, according to the measurements performed. 


\section{Genetic distance}

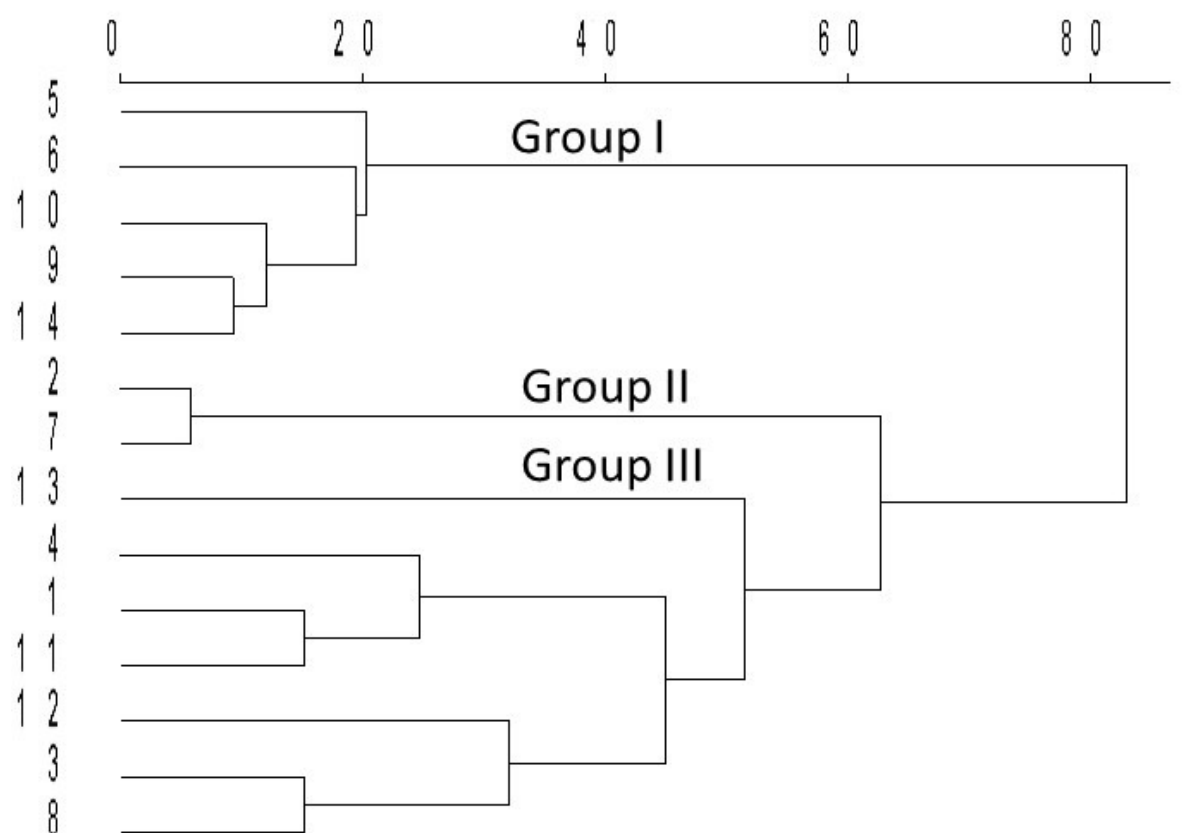

Figure 1. Dendrogram resulting from the analysis of 14 species of Passiflora based on 12 traits of resistance to F. solani, obtained by the UPGMA clustering method and using the Mahalanobis distance as the genetic distance measurement. The numbers refer to the following species: 1- P. quadrangularis, $2-P$. nitida, 3-P. foetida, 4- P. eichleriana, 5- P. alata, 6- P. setacea, 7- P. cincinnata, 8- P. mucronata, 9- $P$. micropetala, 10- P. suberosa, 11- P. morifolia, 12- P. tenuifila, 13- P. edulis, and 14- P. coccinea.

Group 2 is composed of the most resistant species, namely, $P$. nitida and $P$. cincinnata. These species showed lower values for almost all traits. Besides, the plants eventually began to recover from necrosis caused by pathogen colonization. Finally, the group that allocated most species is formed by moderately resistant genotypes, which are: $P$. edulis, $P$. eichleriana, $P$. quadrangularis, $P$. morifolia, $P$. tenuifila, P. foetida and P. mucronata.

According to Assmann et al. (2010), the achievement of clusters with epidemiological similarities within the group and differences between the groups shows that this type of analysis can effectively distinguish and group genotypes according to the degree of sensitivity to disease, which is useful for breeding programs.

The coffenetic correlation coeficient (ccc), obtained from generalized distance matrix and coffenetic distance matrix was 0.7 - exposing a reasonable adjustment between graphic representation of distance and its original matrix, allowing the performance of inferences by visual assessing picture 1. Cerqueira -Silva et al (2010), when working with genetic diversity of Passiflora species found a ccc 0.6 smaller than the one assessed in this work.
Canonical variate analysis is another grouping method frequently used in multivariate analysis whose purpose is to identify similar genotypes in two- or three-dimensional scatterplots, so as to simplify the interpretation of results. The viability of its interpretation is restricted to the concentration of variability among the first variables, usually above $80 \%$ (CRUZ et al., 2004). This study found that the first three variables explain $81.60 \%$ of the total variation. Thus, it is possible to satisfactorily explain the variability observed for stalk rot between Passiflora species. Therefore, the use of the canonical variate analysis is appropriate because it provides structural data simplification.

The groups formed in the three-dimensional dispersion (Figure 2) were similar to those formed in the dendrogram. This analysis shows that the most susceptible and resistant species formed basically groups similar to those presented in the dendrogram, except for the inclusion of the species $P$. tenuifila (12) in group I. Besides, in this method, another group was formed with the species $P$. Edulis (13), which had been allocated in Group III in the previous assessment. In this group, it was isolated. 


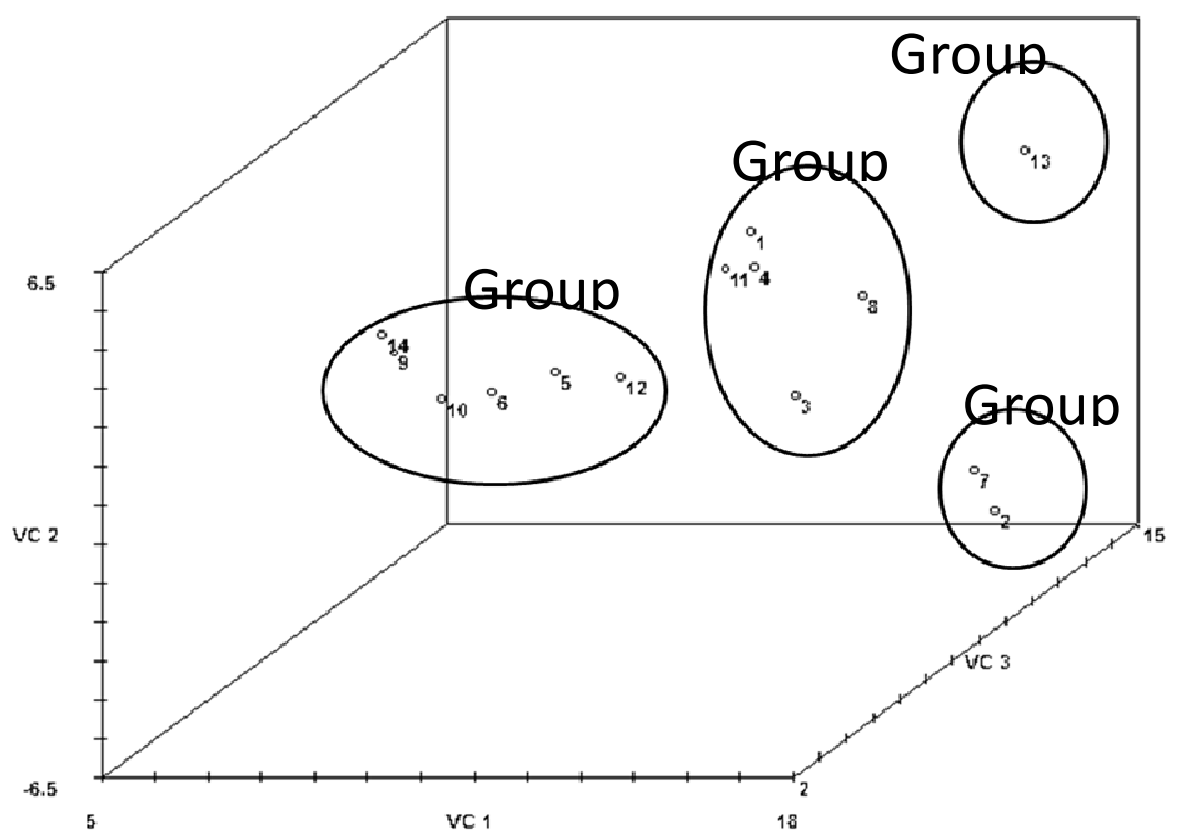

Figure 2. Graphic dispersion of 14 Passiflora species, in relation to the first three canonical variables $\left(\mathrm{VC}_{1}\right.$, $\mathrm{VC}_{2}$ and $\mathrm{V}_{3}$ ). 1- P. quadrangularis, 2- P. nitida, 3-P. foetida, 4- P. eichleriana, 5- P. alata, 6- $P$. setacea, 7- P. cincinnata, 8- P. mucronata, 9- P. micropetala, 10- P. suberosa, 11- P. morifolia, 12- P. tenuifila, 13- $P$. edulis, 14- $P$. coccinea.

Assmann et al. (2010) and Suinaga (2003) also used the UPGMA cluster analysis and graphical dispersion to evaluate the dissimilarity of peach genotypes associated with resistance to leaf rust and of Lycopersicon spp. Genotypes related to resistance to Tuta absoluta, respectively. In agreement with this study, it was observed the efficiency of methods that, through a set of resistance traits, allowed the formation of clusters of genotypes that showed genetic diversity for resistance.

Regarding the relative contribution of each trait of resistance to $F$. solani for genetic diversity among Passiflora species (Table 1), based on the criterion proposed by Singh (1981), it is observed that, for the 14 species under study, we have, in descending order of contribution of the traits, PLA $+50 \%$, AACEAL, NPL-50\%, NPLAM, NPM, LL, CL, PILA100\%C, AACECL, PIPM, PS and AACELL. Thus, the traits PLA+50\%, AACEAL, NPL-50\%, NPLAM, NPM contributed with $80.1 \%$ of the total distribution and are considered important in the characterization of species resistant to $F$. Solani. They are, therefore, essential in works aimed at assessing Passiflora genetic resistance to this pathogen.

The inoculation period until the injury reaches more than $50 \%$ of the circumference of the injured stem provided the highest contribution, $25.28 \%$, to the genetic diversity of the species for resistance to $F$. solani. This trait is essential for breeding programs which focus on resistance to this disease, since the faster the lesion advances in the circumference stem, the faster the plant comes into senescence and becomes more susceptible. The AACELL characteristic disclosed the smallest estimative of S.J., being this way, it is not relevant for distinguishing resistant specie - confirming Test $\mathrm{F}$ and it did not show us significative difference and the variation we may notice can be assign by chance. The AACECL characteristic few contributed with genetic diversity to resistance (stem rot) and also did not presented significance by $\mathrm{F}$ testing it. In spite of its little contribution to diversity, most authors do not recommend the disposal of this trait (SUINAGA et al., 2003; MARIM et al., 2009) (Table 2).

Considering the large number of plants investigated in breeding programs for resistance to disease, the traits PLA+50\%, NPL-50\%, NPLAM and NPM proved to be the most suitable components for use in selection works for being easier to assess, and for their speed, efficiency and reliability in the selection of species resistant to $F$. solani, compared to the injured area (AACEAL, AACELL, AACECL). The latter presents good results, but its evaluation is very time consuming. 
Table 2. Estimated relative contribution of the 12 traits resistant to $F$. solani (S.j) for genetic divergence among 14 Passiflora species, based on the generalized Mahalanobis distance.

\begin{tabular}{ccc}
\hline \multirow{2}{*}{ Variables } & \multicolumn{2}{c}{ Relative contribution } \\
\cline { 2 - 3 } S. j & $\%$ \\
\hline LL & 373,216483 & 4,576565 \\
CL & 378,521675 & 4,64162 \\
NPM & 578,618449 & 7,095305 \\
PS & 36,774317 & 0,450945 \\
PILA+50\% & 2061,82126 & 25,28307 \\
PIPM & 159,703291 & 1,958361 \\
PILA100\%C & 366,174167 & 4,490208 \\
AACEAL & 1760,615471 & 21,58954 \\
AACELL & 33,268688 & 0,407957 \\
AACECL & 274,096339 & 3,361105 \\
NPLAM & 1005,628129 & 12,33151 \\
NPL-50\%P & 1126,509872 & 13,81382
\end{tabular}

\footnotetext{
* LL width of lesion; CL - lesion length; NPM- number of dead plants; PS - survival period; PILA + 50\% - period from inoculation until the lesion reaches more than $50 \%$ of the circumference of the plant; PIPM- Period from inoculation until the plant withers; PILA100\%C - period from inoculation until the lesion reaches $100 \%$ of the circumference of the plant; AACEAL- normalized area under the expansion curve of the area of the lesion; AACELL- normalized area under the curve of expansion of lesion width; AACECLnormalized area under the curve of the length of the lesion; NPLAM- number of plants whose injury reaches the marrow of the plant; NPL-50\% P- number of plants whose injury reached less than $50 \%$ of the circumference of the plant.
}

Based on the results presented above, the species most resistant to stem rot were $P$. nitida and $P$. cicinnata. In their work, Fischer et al. (2005) evaluated the behavior of different species of the genus Passiflora in the presence of $F$. solani, and also found resistance in the species $P$. nitida. Therefore, the same results were not found for the species $P$. cincinnata and $P$. alata, since in this study they showed high resistance and high susceptibility, respectively.

Fischer et al. (2010b) conducted studies in orchards where the disease had occurred and found that the species $P$. alata and $P$. suberosa used as rootstock were more resistant to stem rot compared to the non grafted plants. In this study, under controlled conditions, the same species exhibited little resistance to the disease. This resistance variation in plants of the same species may be associated with genetic diversity within Passiflora species.

The combined effect of the 12 traits used, because it is an analysis that allows integrating multiple information of a set of traits, extracted from the experimental units, help to explain the resistance of the species $P$. nitida and $P$. cincinnata compared to more susceptible species, $P$. alata, $P$. suberosa, . setacea, $P$. micropetala and $P$. coccinea.
For all these species classified as susceptible, it was observed the death of more than $50 \%$ of the plants and higher values for the size of the injury. Suinaga et al. (2003) also used the combinatorial effect of traits of resistance to study the genetic diversity of Lycopersicon spp. related to the Tuta absoluta attack. Thus, similarly to the work of Suinaga et al. (2003), it was possible to identify the most divergent and similar species, adjust the resistance assessment methodology and choose the best genotypes for breeding programs.

The use of multiple traits to select resistant genotypes through biometrics allows greater accuracy of results, and suggests the use of the species $P$. nitida and $P$. cincinnata as sources of resistance to $F$. solani. Besides being rustic and resistant to diseases, $P$. nitida has great potential for use in breeding programs involving inter-specific hybridization (JUNQUEIRA et al. 2010).

\section{CONCLUSIONS}

The traits that contributed most to genetic diversity were the period from inoculation until the lesion reaches more than $50 \%$ of the circumference of the injured stem and area under the curve of expansion of the width of the injury. 
The biometric methods, canonical variables and UPGMA presented similar grouping, and their use represented more accuracy and reliability to the selection of Passiflora species resistant to F. Solani. The most resistant species we found were $P$. nitida and $P$. cincinnata.

RESUMO: A podridão do colo é uma doença de difícil controle e que em muitas regiões do Brasil tem dificultado o cultivo do maracujazeiro. Neste contexto, este estudo teve por objetivos avaliar resistência genética em espécies de Passiflora ao fungo Fusarium solani utilizando análise multivariada como metodologia para distinguir as espécies quanto à resistência. Foram avaliadas 14 espécies de Passiflora, sendo elas: P. quadrangularis, $P$. nitida, $P$. foetida, P. tenuifila, P. alata, P. setacea, P. cincinnata, P. mucronata, P. micropetala, $P$. suberosa, P. morifolia, $P$. eichleriana, $P$. edulis e $P$. coccinea. Estas plantas foram dispostas em blocos ao acaso com 14 tratamentos (espécies), três repetições e três plantas por parcela. A reação das espécies de Passiflora inoculadas foi avaliada utilizando 12 características de resistência. Através dessas características, por meio da distância generalizada de Mahalanobis, foram realizados agrupamentos pelo método UPGMA, projeção 3D com as variáveis canônicas e também foi quantificada a contribuição relativa dos caracteres. Verificou-se, por meio do método de agrupamento UPGMA, a formação de três grupos distintos de espécies, e estes foram classificados como sendo suscetíveis, moderadamente resistentes e resistentes. Os agrupamentos formados pela dispersão tridimensional se assemelharam aos formados pelo dendrograma. As características que mais contribuíram para a diversidade genética foram período da inoculação até a lesão atingir mais que $50 \%$ da circunferência do caule lesionado e área abaixo da curva de expansão da largura da lesão. O uso do conjunto de características e a avaliação conjunta das mesmas através de análise multivariada possibilitaram maior acurácia na inferência das espécies mais resistentes, destacando-se $P$. nitida e $P$. cincinnata.

PALAVRAS-CHAVE: Maracujazeiro. Fusarium solani. Resistência genética.

\section{REFERENCES}

ASSMANN, A. P.; CITADIN, I.; SANTOS, I.; WAGNER JÚNIOR, A. Reação de genótipos de pessegueiro à ferrugem-da-folha. Pesquisa Agropecuária Brasileira, Brasília, v. 45, n. 1, p. 32-40, jan. 2010. http://dx.doi.org/10.1590/S0100-204X2010000100005

BERNACCI, L. C.; CERVI, A. C.; MILWARD-DE-AZEVEDO, M. A.; NUNES, T. S.; IMIG, D. C.; MEZZONATO, A. C. Passifloraceae. In: Lista de espécies da flora do Brasil. Jardim Botânico do Rio de Janeiro. Disponível em: <http://www.floradobrasil.jbrj.gov.br/jabot/ floradobrasil/FB12506>. Acesso em: 30 set. 2014.

CERQUEIRA-SILVA, C. B. M.; CARDOSO-SILVA, C. B.; SANTOS, E. S. L.; CONCEIÇÃO, L. D. H. C. S.; PEREIRA, A. S.; OLIVEIRA, A. C.; CORREAA, R. X. Genetic diversity in wild species of passion fruit (Passiflora trintae) based on molecular markers. Genetics and Molecular Research, v. 9, n. 4, p. 2123-2130, out. 2010. http://dx.doi.org/10.4238/vol9-4gmr875

CRUZ, C. D., REGAZZI, A. J., CARNEIRO, P. C. S. Modelos biométricos aplicados ao melhoramento genético. Viçosa: Universidade Federal de Viçosa, 2004. v. 3. 480 p.

CRUZ, C. D. GENES: a software package for analysis in experimental statistics and quantitative genetics. Acta Scientiarum Agronomy, Maringá, v. 35, n. 3, p. 271-276, set. 2013.

CUNHA, M. A. P.; BARBOSA, L. V.; JUNQUEIRA, N. T. V. Espécies de maracujazeiro. In: LIMA, A. A. (Ed.). Maracujá produção: aspectos técnicos. Brasília: Embrapa Informação Tecnológica, 2002. 104 p.

FISCHER, I. H.; MARTINS, M. C.; LOURENCO, S. A.; KIMATI, H.; AMORIM, L. Reação de espécies de Passiflora à podridão do colo, causada por Fusarium solani e Phytophthora nicotianae. Fitopatologia

Brasileira. Brasília, v. 28, p. 271. 2003. 
FISCHER, I. H.; LOURENÇO, S. A.; MARTINS, M. C.; KIMATI, H.; AMORIM, L. Seleção de plantas resistentes e de fungicidas para o controle da podridão do colo do maracujazeiro causada por Nectria haematococca. Fitopatologia Brasileira, Brasília, v. 30, n. 3, p. 250-259, jun. 2005.

FISCHER, I. H.; RESENDE, J. A. M. Diseases of Passion Flower (Passiflora spp.). Global Science Books, Kagawa, v. 2, n. 1, p. 1-19, abr. 2008.

FISCHER, I. H.; BUENO, C. J.; GARCIA, M. J. M.; ALMEIDA, A. M. Reação de maracujazeiro-amarelo ao complexo fusariose-nematoide de galha. Acta Scientiarum Agronomy. Maringá, v. 32, n. 2, p. 223-227, jun. 2010a.

FISCHER, I. H.; ALMEIDA, A. M.; FILETI, M. S.; BERTANI, R. M. A.; ARRUDA, M. C.; BUENO, C. J. Avaliação de Passifloraceas, fungicidas e Trichoderma para o manejo da Podridão-do-colo do maracujazeiro, causada por Nectria haematococca. Revista Brasileira de Fruticultura. Jaboticabal, v. 32, n. 3, p. 709-717, set. $2010 \mathrm{~b}$.

FRY, W. E. Integrated control of potatoes late blight: effects of polygenic resistance and techniques of timing fungicide application. Phytopathology, v. 67, n. 3, p. 415-420, 1977. http://dx.doi.org/10.1094/Phyto-67-415

IBGE, Instituto Brasileiro de geografia e estatística. Banco de dados agregados: Produção Agrícola Municipal, 2009. Disponível em: <http://biblioteca.ibge.gov.br/visualizacao/periodicos/20/aeb_2012.pdf>. Acesso em: 08 nov. 2014.

JUNQUEIRA, N. T. V.; SANTOS, E. C. D.; JUNQUEIRA, K. P.; FALEIRO, F. G.; BELLON, G.; BRAGA, M. F. Características físico-químicas e produtividade de acessos de Passiflora nitida Kunth procedentes do centro-norte do Brasil. Revista Brasileira de Fruticultura, Jaboticabal, v. 32, n. 3, p. 791-797, set. 2010.

MARIM, B. G.; SILVA, D. D.; CARNEIRO, P. C. S.; MIRANDA, G. V.; MATTEDI, A. P.; CALIMAN, F. R. B. Variabilidade genética e importância relativa de caracteres em acessos de germoplasma de tomateiro.

Pesquisa Agropecuária Brasileira, Brasília, v. 44, n. 10, p. 1283-1290, set. 2009.

http://dx.doi.org/10.1590/S0100-204X2009001000011

MELETTI, L. M. M.; BRUCKNER, C. H. Melhoramento genético. In: BRUCKNER, C. H.; PICANÇO, M. C. (Ed.). Maracujá: tecnologia de produção, pós-colheita, agroindústria, mercado. Porto Alegre: Cinco Continentes, 2001. p. 345-385.

MELETTI, L. M. M. Avanços na cultura do maracujá no Brasil. Revista Brasileira Fruticultura, Jaboticabal, Volume Especial, p. 83-91, out. 2011.

SHANER, G.; FINNEY, R. E. The effect of nitrogen fertilization on the expression of slow-mildewing resistence in knox wheat. Phytopathology, v. 67, n. 8, p. 1051-1056, 1977. http://dx.doi.org/10.1094/Phyto$67-1051$

SILVA, A. N.; AZEVEDO, G. B.; ROCHA-SOBRINHO, G. G.; NOVAES, Q. S. Efeito de produtos químicos e de Trichoderma spp. no controle de Fusarium solani do maracujazeiro. Interciencia, Vera Cruz Street, v. 39, n. 6, p. 398-403, jun. 2014.

SINGH, D. The relative importance of characters affecting genetic divergence. The Indian Journal of Genetic and Plant Breeding. v. 41, n. 2, p. 237-245, 1981.

SUINAGA, F. A.; CASALI, V. W. D.; SILVA, D. J. H.; PICANÇO, M. C. Dissimilaridade genética de fontes de resistência de Lycopersicon spp. a Tuta absoluta (meyrick, 1917) (Lepidoptera: Gelechidae). Revista brasileira de Agrociência, Pelotas, v. 9, n. 4, p. 371- 376, out-dez. 2003. 